Provided for non-commercial research and education use. Not for reproduction, distribution or commercial use.

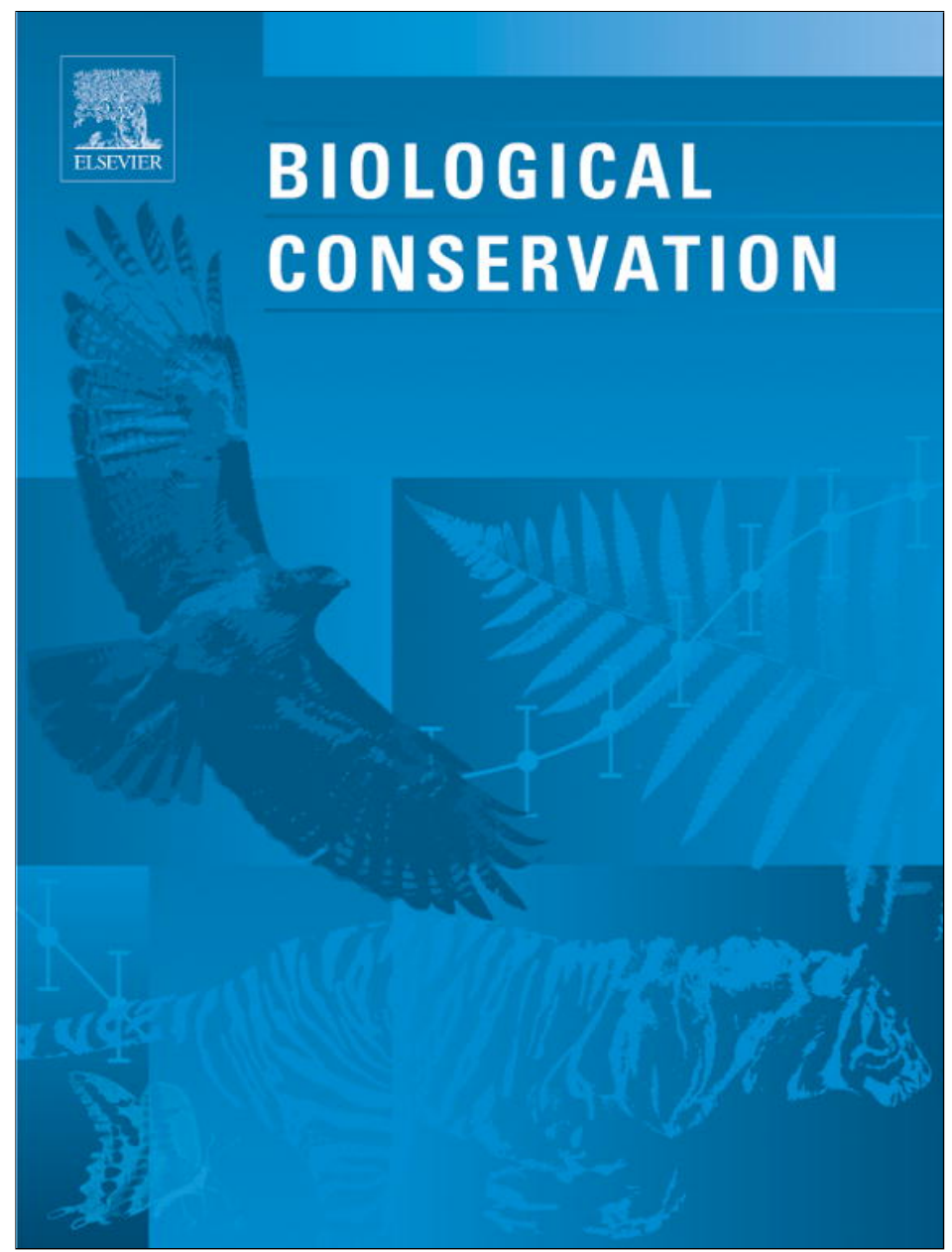

This article appeared in a journal published by Elsevier. The attached copy is furnished to the author for internal non-commercial research and education use, including for instruction at the authors institution and sharing with colleagues.

Other uses, including reproduction and distribution, or selling or licensing copies, or posting to personal, institutional or third party websites are prohibited.

In most cases authors are permitted to post their version of the article (e.g. in Word or Tex form) to their personal website or institutional repository. Authors requiring further information regarding Elsevier's archiving and manuscript policies are encouraged to visit:

http://www.elsevier.com/authorsrights 
Perspective

\section{Beyond prejudice: Conservation in the City. A case study from Switzerland}

\section{Joëlle Salomon Cavin*}

Institute of Geography and Sustainability, University of Lausanne, Geopolis, CH-1015 Lausanne, Switzerland

\section{A R T I C L E I N F O}

\section{Article history:}

Received 14 January 2013

Received in revised form 6 June 2013

Accepted 14 June 2013

\section{Keywords:}

Anti-urban bias

Natural value

Natural parks

City

Switzerland

\begin{abstract}
A B S T R A C T
Conservation in the City is challenging because of a continued view that the urban realm is antithetical to nature. This was clearly the case when the first Swiss National Park was established at the beginning of the 20th century. New Swiss legislation brought new approaches to the establishment of natural parks, in particular by including human activities as a logical component in their development. In 2010, a Federal think tank discussed opportunities for launching a new kind of park: the Urban Natural Park. This paper reports an analysis of this discussion, together with the study of the literature dealing with conservation in the City and natural parks. It shows that a clear antagonism between city and nature still remains present, reflected in an implicit hierarchy hidden in the designation of natural parks: wild nature is nominated as the best nature; if not wild, the best nature is identified as rural; if neither wild nor rural, nature is thought not to be the concern of natural park policy. The Swiss Biodiversity Strategy implemented in 2012 is a recent recognition of the importance of urban nature for biodiversity conservation. This recognition, however, condemns urban nature to a special status, situated outside the usual framework of conservation management. I conclude by arguing that anti-urban bias must be addressed because it inhibits effective conservation strategy, prevents the identification of existing environmental qualities of cities and, eventually, has negative impacts on biological conservation outside the city because it fosters urban spreading.
\end{abstract}

\section{Contents}

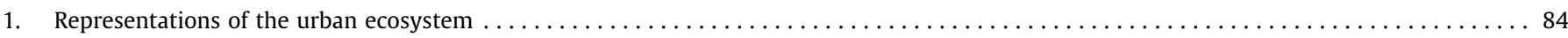

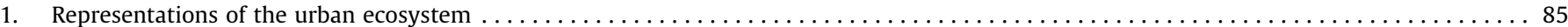

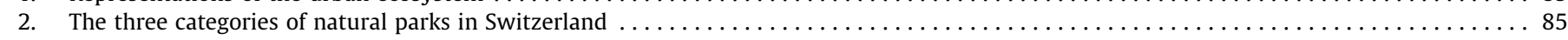

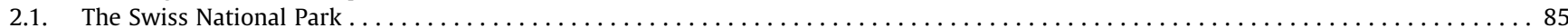

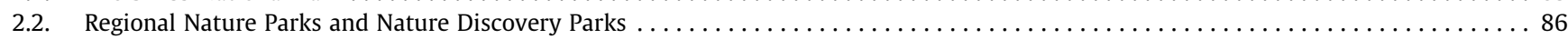

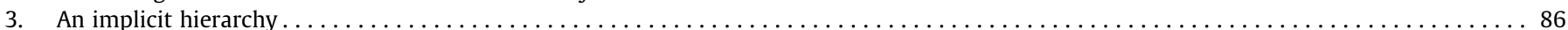

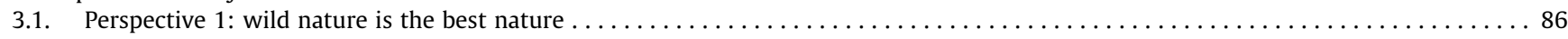

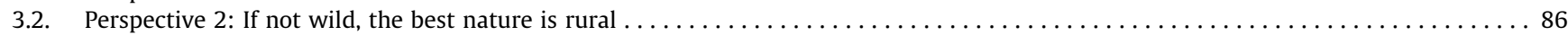

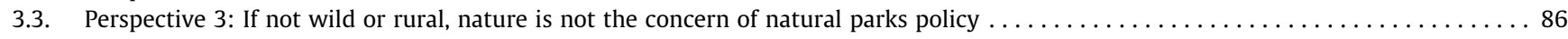

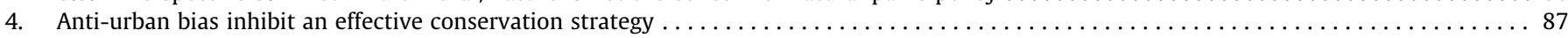

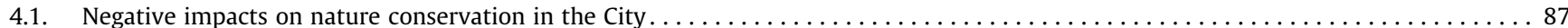

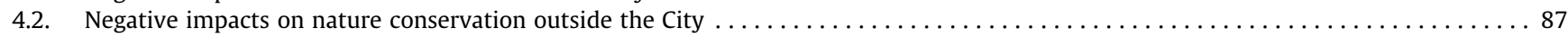

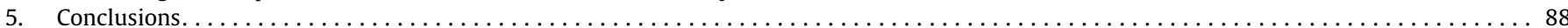

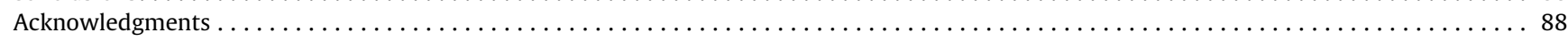

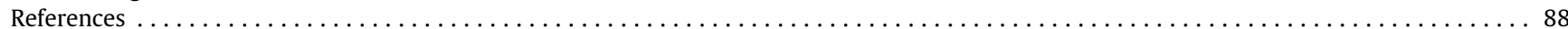

\footnotetext{
* Tel.: +41 2169235 61; fax: +412169235 55 .

E-mail address: Joelle.salomoncavin@unil.ch
} 


\section{Representations of the urban ecosystem}

For conservation biologists, cities are generally not recognised as a major target for conservation measures (Sanderson and Huron, 2011). There is a traditional reluctance of ecologists and conservationists to focus on areas dominated by human activities (Miller and Hobbs, 2002; Dearborn and Kark, 2009). Urban ecosystems have long been neglected with ecologists focusing their research on areas located distant from urban environment. Recent content analysis of mainstream conservation biology journals (e.g. Conservation Biology, Biological Conservation, Biodiversity and Conservation) shows a persistent focus on relatively intact, non-urban, habitats (Fazey et al., 2005).

In the meantime, an increasing number of studies have considered urban ecosystems (McKinney, 2008; Kowarik, 2011; Scheffers and Paszkowski, 2012). Some of these researchers have obtained counterintuitive results, for instance: positive correlations between habitat variability in cities and plant species richness; higher species richness for both native and non-native species in urban areas than in countryside areas (Kühn et al., 2004; Wania et al., 2006; Fontana et al., 2011) and even evidence that urban areas can represent refugia for species endangered by intensive agriculture (Pyšek, 1998).

Consequently, there is a growing awareness of the need to preserve urban biological diversity (Dearborn and Kark, 2009; Kowarik, 2011). This new demand for biological conservation in cities (Sanderson and Huron, 2011) can also be associated to a "new" or "non-equilibrium" ecology (Wallington and Hobbs, 2005), in which change and contingency - rather than stability are regarded as the norm. Disturbances, such as human influences, are considered as internal components of the system rather than external factors (Wallington and Hobbs, 2005; Head, 2007). This approach can also be understood in the light of Rosenzweig's "reconciliation ecology" (Rosenzweig, 2003), which focuses on inventing, establishing and maintaining new habitats to conserve species diversity in places where people live (Dearborn and Kark, 2009). Here, conservation science not only works to prevent a loss of nature but also to foster the creation of "new" nature (Sanderson and Huron, 2011) or "second nature" (Zimmerer, 2000). Such an approach is sensitive to the social benefits of biodiversity and other ecosystems services associated with urban nature (Savard et al., 2000; Chiesura, 2004; Fuller et al., 2007) and regarded as providing new reasons for enhancing conservation activities where people live and work (Miller and Hobbs, 2002).

Nevertheless, the fundamental value of conserving urban biodiversity remains controversial, something that in turn requires creativity in setting conservation goals (Dearborn and Kark, 2009; Hostetler et al., 2011). Because it is synonymous of pollution, human disturbances, pressure of alien species, habitat fragmentation, etc., the urban realm always seems to be a less appropriate location for actions regarding biological conservation. (Miller and Hobbs, 2002; McKinney, 2008; Sattler et al., 2010; Kowarik, 2011; Scheffers and Paszkowski, 2012). Moreover, conservation efforts are inevitably limited by money. For instance, land is limited and expensive in urban environments creating a disincentive for future acquisition and protection.

In this paper, I extend this argument by arguing that not only is this because cities are ecologically disturbed regimes, but also there is a deep cultural prejudice that prevents conservation practices in the city being realised. I argue that this issue is not only grounded in the physical features of city, but also in its negative image. I focus on the case of the Swiss National Park in order to illustrate the impact of anti-urban bias on conservation policy at the beginning of the twentieth century. This is followed by consideration of an observed shift in the nature/city relationship exemplified by recent new Swiss laws, which define new categories of natural parks. In the third part, I consider the impact of anti-urban bias on conservation policies and conservation sciences (see Table 1 ).

I have used two primary sources of evidence to assess the degree of anti-urban bias in the definition and setting up of natural parks in Switzerland. The first source is based on discussions of a think tank established by the Swiss Federal Office for the Environment in 2010 in order to set up the definition of a new category of Urban Natural Parks in Switzerland. The sources for this research were collected during two meetings of this group in July and September 2010 and completed using the unpublished reports of this think tank. The sources were collected when the author was a participant observer at these meetings. The group was composed of 22 members (the majority had a background in ecology or biology). These individuals represented: the Swiss Federal Office for the Environment, Cantonal Environmental Services, Swiss Natural Parks and Swiss organizations for the protection of nature. I was invited as an academic interested in city-nature relationships in Switzerland. A second source of data was provided by the analysis of scientific literature dealing on the one hand with biological conservation in the City and on the other hand with the evolution of the conception of natural parks, mostly in Switzerland.

\section{The three categories of natural parks in Switzerland}

There are three categories of natural parks in Switzerland. The category National Park was created at the beginning of the 20th century and legally defined by a Federal law in 1980. The categories Regional Nature Park and the Nature Discovery Park were created and legally defined in 2006.

\subsection{The Swiss National Park}

The first and only Swiss National Park was founded in 1914. Following the USA's founding of Yellowstone (1872) and Yosemite (1890), Switzerland was one of the first European nations to do so. The choice of a large territory in the Graubünden canton, eastern Switzerland, rested on the remoteness of the region. For the stakeholders in charge of conservation in the park, the genuine - or good - nature was the one which was out of human touch: "nature left to itself in its powerful savagery, only master of its destiny, having reclaimed its independence as in the days that preceded the

Table 1

Location and target of the three official categories of Natural Parks in Switzerland. The creation of the category of Urban Natural Park has been eventually rejected. This new category would have filled out a lack in regard to the urban anthropised natural areas in the natural park policy. Adapted from Galland, P., (unpublished report). Nouvelle catégorie de parc. Rapport du groupe de travail. Office fédéral de l'Environnement, Bern.

\begin{tabular}{lll}
\hline & & Location \\
\cline { 3 - 3 } & & Rural \\
\hline Natural target & Natural/sub-natural areas & National Park \\
& Anthropised natural areas & Regional Natural Park \\
\hline
\end{tabular}

a The Nature Discovery Parks (which have been called in French : "Peri-urban Natural parks") cannot be situated within the cities but in densely populated regions within a $20 \mathrm{~km}$ radius from the centre of an agglomeration. 
dominance of the human" (Ligue suisse pour la protection de la nature, 1937: 25 , author's translation). This view is very similar to the wilderness ideal of the North America movement (Nash, 2001; Owen, 2009) and also to a kind of "a historical pure ecosystem" identified by Mels in his study of Swedish National Parks (Mels, 2002).

The Federal Law on Nationals Parks (1980) re-affirmed this notion. The National Park should be "a reserve in which nature is untouched by human activities and in which the fauna and flora are free to evolve naturally" (Assemblée fédérale de la Confédération suisse, 1980). Cities are excluded from the National Park, both topologically and conceptually as humanised places. This "wilderness based conservation is rooted in an incompatibility between biodiversity and heavy human presence" (Dearborn and Kark, 2009). Implicit in the original designation of national parks in Switzerland and in the law is the belief that they should be regarded as the translation of an ideal separation between society (humanity) and nature. They are conceived as a sanctuary which should preserve an untouched nature from anthropic disturbance.

\subsection{Regional Nature Parks and Nature Discovery Parks}

The opposition between man and nature and the idea that nature lies outside the city was intrinsically attached to the historical definition of the National Park. But, this antagonistic conception has been altered recently in Swiss law. A partial revision of the Federal Law concerned with nature protection (Assemblée fédérale de la Confédération Suisse, 1980 modified in: art 23f.3) in 2006 establishes and defines two new parks and clarifies the definition of the National Park. The new law was a conceptual shift in the relationship between human activities and nature conservation. The three categories of parks are designed on the basis of "a harmonious combination of land conservation and landscape conservation" with "regional development" (Conseil Fédéral, 2005: 2022). With these new definitions, human activities are now tolerated within the National Park. Their main objective is to achieve a balance between nature and human uses. Thus, the new categories of parks are explicitly designed as a contrast to the "closed jar approach" (Fall, 2004; Head, 2007) in which nature is isolated from the human world.

More specifically, the Regional Nature Park aims to comprise an extensive, partly populated rural area characterised by high natural and landscape values but that also promotes sustainable development of the regional economy. In other words, in this park, nature is part of a culturally shaped landscape, one both inhabited and exploited. Some kinds of agricultural activities, such as grazing, are not regarded as a threat to biodiversity, but as a necessity for its preservation. Humans are no longer considered de facto as destructors of biodiversity, but instead as actors who can help to maintain it.

The Nature Discovery Parks are areas situated in densely populated regions (within a $20 \mathrm{~km}$ radius from the centre of an agglomeration, at a similar elevation and easily accessible by public transportation). They aim to comprise "sub-natural" areas, suitable for environmental education involving experiences of nature that should improve the quality of life for city dwellers (Conseil Fédéral, 2005: 2033). In this park, the relationship between protected nature and human population is regarded as a key point objective in its definition.

\section{An implicit hierarchy}

The study of the history of the establishment of natural parks in Switzerland shows that although an integration of human activities with natural ecosystems is considered, a clear antagonism between densely populated areas and the idea of nature is still present. This antagonism is manifested as an implicit hierarchy, hidden in the design of the new concept of parks, which is here outlined according to three perspectives.

\subsection{Perspective 1: wild nature is the best nature}

Both National Park and Nature Discovery Park include a core zone, which is defined as follows: "in the core zone, nature is not subject to human intervention and is left to its own dynamics" (Conseil Fédéral, 2005). This core zone is surrounded by a peripheral zone, defined as a "place for human activities". In the central core, such a "left to its own" dynamics requires that nature should be as much as possible untouched by human disturbance. Thus, in order to allow "the free development of natural processes" (Conseil Fédéral, 2007: art. 23), the construction of buildings, as well as farming and forestry are prohibited, except for traditional pastoral farming. In this approach, human beings are regarded as opposed to natural processes. This position is the most antagonistic conception of the society/nature relationship, in which human activity is still considered as a priori harmful to natural ecosystems, whilst possible natural disturbances are regarded as neutral. It extends the former creation of the Swiss National Park, and the view that nature is "better" when it remains outside human influence. The definition of this central area dramatically restricts the amount of potential areas that could be labelled as Nature Discovery Park. It excludes environments, which require regular maintenance to secure their perenity, such as lowland wetland areas (e.g. marshes and lakes) because of an extensive regulation of Swiss rivers for hydro-electric power (Ejderyan, 2009). Indeed, because of these restrictive conditions, only a single Nature Discovery Park has been established in Switzerland: the Park of Sihlwald near Zurich in 2011.

\subsection{Perspective 2: If not wild, the best nature is rural}

In the new definition of the three categories of natural parks, human activity becomes well-tolerated provided it is regarded as rural and traditional. In the National Park, it is considered that if nature cannot be "left to itself" in a core zone, then the compromise is to label nature as rural. The same rule is applied in the Nature Discovery Parks to distinguish the center from the other parts of the park. The Regional Natural Parks are always located in extensive rural areas. Thus, the features of traditional rural buildings and agricultural uses are valued $a$ priori as closer to nature than urban buildings and uses. The landscape value of an area is assessed according to its orchards, closes, pastures, vineyards and fields that surround it. In this category of park, the opposition between city and nature remains, but it becomes re-expressed as an antagonism between city ("un-natural") and countryside ("more natural"). Faced with human activity, the countryside is presumed to be the place where nature is still at its most authentic when compared to city.

\subsection{Perspective 3: If not wild or rural, nature is not the concern of natural parks policy}

In 2010, the Canton of Argovia approached the Federal Office of the Environment to suggest a possible candidate for a natural park in the region of Wasserschloss. This region is located at the confluence of three rivers, the Aare, Reuss and Limmat. The Argovian authorities sought to preserve intact non-urbanised areas along rivers by controlling the extension of building zones and to promote recreational activities in more natural settings. ${ }^{1}$

1 Galland, P., (unpublished). Protokoll-Sitzung Arbeitsgruppe "neue Parkkategorie", Bern, p. 2. 
Following an initial discussion, it was planned to integrate this new site into the category of a Nature Discovery Park. However, after comparison of the composition of the proposed park's natural environment with its land use and with legal criteria, it became clear that the region of Wasserschloss did not fit the conditions of this category of park. More specifically, it was not possible to find a central core area consistent with a total area of at least $4 \mathrm{~km}^{2}$; However, considering that there was a clear interest for protecting this unique natural area in the long term, the Federal authority launched a discussion on the opportunity to establish a new category of park: the Urban Natural Park.

The conclusion of the think tank established by the Federal Office for the Environment was to renounce creating a new category of park. The main concern was that such establishment would "weaken" and "dilute" the criteria defining natural parks. ${ }^{2}$ In particular, the issue of the core zone was decisive because it appeared from the start as a necessary component of any Urban Natural Park, even though such areas cannot be found in likely candidate areas.

Eventually, the think tank's discussions concluded that solutions for conservation of natural areas in the city are to be found in the frame of regional planning and urban development policy, and not in conservation policy. This abandonment of a fourth category of park illustrates the problematic nature of the idea of conservation in the City (Sanderson and Huron, 2011). Urban natural areas of any size (except natural items, which benefit specific regulation for their conservation, such as the inscription on Federal Inventories of Natural Monuments of National Importance) are not considered sufficiently biological significant to be protected as a natural park. Consequently, those urban areas are deprived of funding and of all benefits of nature conservation attached to natural parks.

\section{Anti-urban bias inhibit an effective conservation strategy}

Discussing the definition of natural parks, and more specifically the recent failure to implement a new category of parks to preserve nature in urban environments, illustrates an on-going anti-urban bias, which impacts conservation in Swiss cities. This may reflect more general anti-urban trends and common representations in conservation biology.

Despite the evolution of the idea of urban nature during recent decades, a constant view of the urban realm as fundamentally antithetical to nature is still present and, consequently, depresses the presumed natural value accorded to strongly human impacted and human created environments. There remains nostalgia for supposedly untouched and stable ecosystems, far away from urban disturbance. But why does it matter?

\subsection{Negative impacts on nature conservation in the City}

It matters because for decades anti-urban representations have weakened the knowledge and study of urban natural ecosystems as well as the appreciation of their potential role in biological conservation. A second issue is that anti-urban bias inhibits reflexion. It justifies blaming, for instance, the idea that cities are responsible of high levels of greenhouse gas emissions. This statement is true in itself but should be relativized because analysis of emissions inventories shows that per capita emission from cities are lower than the average emissions for the countries in which they are located (Dodman, 2009). Cities are with no doubt engines of consumption but, in the same time, cities can be also environmentally rather efficient places compare to areas of lower population density

\footnotetext{
${ }^{2}$ Galland, P., (unpublished). Nouvelle catégorie de parc. Rapport du groupe de travail. Office fédéral de l'Environnement, Bern.
}

because of smaller living spaces and better public transportation (Owen, 2009).

The issue arises, however, that if anti-urban bias inhibits the recognition of the natural value of city environments, and that the development of policies reflects this trend (e.g. the failure to designate protected areas in urbanised areas), then there is a risk that possible negative impacts upon urban natural ecosystem are not properly identified and managed: perpetuating the image of the city as an environment opposed to nature slows down the protection of the nature that cities contain.

Although anti-urban biases strongly impact the definition of nature by policy makers as observed in the failure of setting up a Natural Urban Park category, they have not prevented the implementation of conservation programs in the city. Recently, the Swiss biodiversity strategy (Federal Council, 2012) ${ }^{3}$ has specifically stressed other values and views of urban nature. In this document, the recognition of the important role of biodiversity in providing key ecosystem services for the society gives a central importance to the conservation of urban biodiversity. This increasing recognition lays clearly outside the concept of nature as it is implied in the definition of natural parks in Switzerland, and reveals that conservation not only concerns the pure and untouched nature located far from the city.

\subsection{Negative impacts on nature conservation outside the City}

Perpetuating the image of the city as an environment hostile to nature impacts on biological conservation outside the city. Antiurban ideologies and their associated rural idylls, are well-known components of urban sprawl (Jackson, 1985). The paradox is that the desire to flee the hostile city and to live close to nature leads to its destruction by spreading urbanisation.

Environmental organizations were the cause, in part, of the establishment of these spatial divisions, sanctuaries, parks, etc. which aim at protecting a vulnerable wild, or rural nature from urban sprawl. Those measures have had unfortunate consequences, as shown in the case of the CPRE (Campaign to Protect Rural England) (Murdoch and Lowe, 2003; Salomon Cavin, 2006). The CPRE was a key advocacy of the zoning in post war England in order to protect natural and rural areas but "[...] as soon as a clear divide between the urban and the rural was defined in policy, it was transgressed in practice. In particular, once the planning system acted to differentiate urban from rural areas, population began to move in ever greater numbers form urban to rural areas to take advantage of the preserved countryside" (Murdoch and Lowe, 2003). Thus, zoning had the effect of making rural areas more attractive. This environmental group found itself in the paradoxical situation of having fostered sprawl, while wanting to protect rural areas. In addition, and equally paradoxically, environmental groups often face the fact that the majority of their members are precisely those involved in the process of urban sprawl. Once they are established outside the city in rural areas, they advocate the prevention of new developments (Murdoch and Lowe, 2003).

Some organizations dealing with conservation have now integrated this paradox of a desire for nature, and its threat to nature conservation, into their actions. Whereas cities were condemned as a threat to nature and as a place with no real nature, cities have become ecologically valued by numerous environment groups (Salomon Cavin et al., 2010). The key idea is that conservation of nature is intrinsically linked to the harmonious development of cities. The more life in the city is satisfactory, the less nature outside

\footnotetext{
${ }^{3}$ The Swiss Biodiversity Strategy is the Swiss contribution to the strategic plan (2011-2020) of the Biodiversity Convention. For details see: http://www.sib.admin.ch/fileadmin/chm-dateien/dokumentation/Publikationen_2012/UD-1060-E_ Stratbiodiv.pdf
} 
the city is affected. The CPRE, for instance, launched the "Going to town" campaign, which aimed at promoting the quality of life in the city (Murdoch and Lowe, 2003; Salomon Cavin, 2006). Crossing boundaries, organizations like the WWF (World Wide Fund For Nature) and Pro Natura are now promoting a positive image of the city as a place where nature and humans can coexist and claim that the sustainable city is a solution to nature conservation (Salomon Cavin et al., 2010; WWF, 2012).

\section{Conclusions}

Despite the re-definition of Swiss natural parks to include the impact of human activities, an anti-urban bias remains apparent in an implicit mental hierarchy. The hierarchy places an untouched wild nature at the top of the scale, above a moderately-anthropised rural nature and eventually a soiled urban nature at the very bottom. This bias affects the definition of nature and, subsequently, the definition of territories concerned by programs of conservation of their natural ecosystems. This case study exemplifies a tendency in conservation policy, which depresses the value of nature within the built environment.

This negative image of the city has to be addressed because it strengthens a trend that devalues the existing environmental qualities of cities. Moreover, it perpetuates tendencies that are, paradoxically, damaging for biological conservation outside the city because it fosters urban spreading.

The recent Swiss Biodiversity Strategy goes clearly in another direction. By highlighting the social values of the urban ecosystem, urban nature is no longer considered as a second-class ecosystem but as a new kind of ecosystem that deserves its own protection. This recent recognition of the quality of urban environments for biodiversity, notably through the social services that they provide, has to be regarded in the light of its implicit values: why is urban nature condemned to be dealt with outside the usual framework of conservation management? Why can't the intrinsic natural value of urban ecosystem be considered simply as nature, and not as urban nature? Should the establishment of conservation strategies and policies be able to grasp the full range of environments, whatever their location, with no special requirements for an urban nature? Beyond prejudice, the challenge for conservation science and policies is to accord conservation significance, currently reserved for sparsely populated and rural regions, to zones of conservation value that are more obviously urban.

\section{Acknowledgments}

I am indebted to the three anonymous reviewers for their thorough examination of the manuscript. I am extremely grateful to L. Cavin, O. Ejderian, J. Fall, G. Hess, S. Lane and N. Mathieu, for providing extensive and insightful comments. I also thank the members of the think tank for their valuable inputs and particularly Pierre Galland, in charge of the theme 'parks of national importance' at the Swiss Federal Office of the Environment, for his support and availability. The present perspective paper is part of the research project "(Re)naturalising cities" funded by the Swiss National Science Foundation (no. 100013_134735). The author also benefited of a grant 'Tremplin' from the equal opportunity office of the University of Lausanne.

\section{References}

Assemblée fédérale de la Confédération suisse, 1980. Loi fédérale sur la Parc national suisse dans le canton des Grisons (Loi sur le Parc National)

Chiesura, A., 2004. The role of urban parks for the sustainable city. Landscape and Urban Planning 68, 129-138. http://dx.doi.org/10.1016/j.landurbplan. 2003.08.003.
Conseil Fédéral (Federal Council), 2005. Message du CF concernant la révision partielle de la loi fédérale sur la protection de la nature et du paysage (LPN) du 23 février 2005.

Conseil Fédéral (Federal Council), 2007. Ordonnance sur les parcs d'importance nationale (OParcs, RO2007-451.36).

Dearborn, D.C., Kark, S., 2009. Motivations for conserving urban biodiversity. Conservation Biology 24, 432-440.

Dodman, D., 2009. Blaming cities for climate change? An analysis of urban greenhouse gas emissions inventories. Environment and Urbanization 21, 185 201. http://dx.doi.org/10.1177/0956247809103016.

Ejderyan, O., 2009. Une renaturation en béton!: comprendre la participation et la nature dans les renaturations de cours d'eau suisses au regard d'une théorie de la pratique, Schriftenreihe Humangeographie. Geographisches Institut Univ. Zürich-Abt. Humangeographie, Zürich.

Fall, J., 2004. Divide and rule: constructing human boundaries in "boundless nature". GeoJournal 58, 243-251.

Fazey, I., Fischer, J., Lindenmayer, D.B., 2005. Who does all the research in conservation biology? Biodiversity and Conservation 14, 917-934. http:// dx.doi.org/10.1007/s10531-004-7849-9.

Federal Council, 2012. Swiss Biodiversity Strategy, Federal Office for the, Environment, 25 April, 2012.

Fontana, S., Sattler, T., Bontadina, F., Moretti, M., 2011. How to manage the urban green to improve bird diversity and community structure. Landscape and Urban Planning 101, 278-285. http://dx.doi.org/10.1016/j.landurbplan. 2011.02.033.

Fuller, R.A., Irvine, K.N., Devine-Wright, P., Warren, P.H., Gaston, K.J., 2007. Psychological benefits of greenspace increase with biodiversity. Biology Letters 390-394.

Head, L., 2007. Cultural ecology: the problematic human and the terms of engagement. Progress in Human Geography 31, 837-846.

Hostetler, M., Allen, W., Meurk, C., 2011. Conserving urban biodiversity? Creating green infrastructure is only the first step. Landscape and Urban Planning 100, 369-371. http://dx.doi.org/10.1016/j.landurbplan.2011.01.011.

Jackson, K.T., 1985. Crabgrass frontier: the suburbanization of the United States. Oxford University Press, New York, Oxford.

Kowarik, I., 2011. Novel urban ecosystems, biodiversity, and conservation Environmental Pollution 159, 1974-1983. http://dx.doi.org/10.1016/ j.envpol.2011.02.022.

Kühn, I., Brandl, R., Klotz, S., 2004. The flora of German cities is naturally species rich. Evolutionary Ecology Research 6, 749-764.

Ligue suisse pour la protection de la nature, 1937. Magazine de la ligue suisse pour la protection de la nature.

McKinney, M.L., 2008. Effects of urbanization on species richness: a review of plants and animals. Urban Ecosystems 11, 161-176. http://dx.doi.org/10.1007/ s11252-007-0045-4.

Mels, T., 2002. Nature, home, and scenery: the official spatialities of Swedish national parks. Environment and Planning D: Society and Space 20, 135-154. http://dx.doi.org/10.1068/d14s.

Miller, J., Hobbs, R., 2002. Conservation where people live and work. Conservation Biology 16, 330-337.

Murdoch, J., Lowe, P., 2003. The preservationist paradox: modernism, environmentalism and the politics of spatial division. Transactions of the Institute of British Geographers 28, 318-332. http://dx.doi.org/10.1111/14755661.00095.

Nash, R.F., 2001. Wilderness and the American Mind. Yale University Press, New Haven.

Owen, D., 2009. Green Metropolis: Why Living Smaller, Living Closer, and Driving Less are Keys to Sustainability. Riverhead Books, New York.

Pyšek, P., 1998. Alien and native species in Central European urban floras: a quantitative comparison. Journal of Biogeography 25, 155-163. http:// dx.doi.org/10.1046/j.1365-2699.1998.251177.x.

Rosenzweig, M.L., 2003. Win-Win Ecology: How the Earth's Species can Survive in the Midst of Human Enterprise. Oxford University Press, Oxford.

Salomon Cavin, J., 2006. La ville au secours de la nature. Une politique urbaine pour l'Angleterre rurale. Espaces et sociétés 126, 141-148.

Salomon Cavin, J., Carron, C., Ruegg, J., 2010. La ville des défenseurs de la nature: vers une réconciliation? Natures, Sciences, Sociétés 18, 113-121. http:// dx.doi.org/10.1051/nss/2010016.

Sanderson, E.W., Huron, A., 2011. Conservation in the City. Conservation Biology 25 , 421-423. http://dx.doi.org/10.1111/j.1523-1739.2011.01683.x.

Sattler, T., Borcard, D., Arlettaz, R., Bontadina, F., Legendre, P., Obrist, M.K., Moretti, M., 2010. Spider, bee, and bird communities in cities are shaped by environmental control and high stochasticity. Ecology 91, 3343-3353. http:// dx.doi.org/10.1890/09-1810.1.

Savard, J.-P.L., Clergeau, P., Mennechez, G., 2000. Biodiversity concepts and urban ecosystems. Landscape and Urban Planning 48, 131-142.

Scheffers, B.R. Paszkowski, C.A., 2012. The effects of urbanization on North American amphibian species: identifying new directions for urban conservation. Urban Ecosystems 15, 133-147. http://dx.doi.org/10.1007/ s11252-011-0199-y.

Wallington, T.J., Hobbs, R.J., 2005. Implications of current ecological thinking for biodiversity conservation: a review of the salient issues. Ecology and Society 10 15, http://www.ecologyandsociety.org/vol10/iss1/art15/.

Wania, A., Kühn, I., Klotz, S., 2006. Plant richness patterns in agricultural and urban landscapes in central Germany-spatial gradients of species richness. Landscape 
and Urban Planning 75 (1-2), 97-110. http://dx.doi.org/10.1016/j.landurbplan. 2004.12.006.

WWF (World Wildlife Fund), 2012. Urban solutions for a living planet - learning cases (Summary), Stockholm.
Zimmerer, K.S., 2000. The reworking of conservation geographies: non equilibrium landscapes and nature-society hybrids. Annals of the Association of American Geographers 90, 356-369. 